University of Nebraska - Lincoln

DigitalCommons@University of Nebraska - Lincoln

US Army Research

U.S. Department of Defense

2003

History of Food Acceptance Research in the US Army

Herbert L. Meiselman

US Army Natick Soldier Center, Natick, MA 01760-5020, USA

Howard G. Schutz

University of California Davis, Davis, CA 95616, USA

Follow this and additional works at: https://digitalcommons.unl.edu/usarmyresearch

Part of the Operations Research, Systems Engineering and Industrial Engineering Commons

Meiselman, Herbert L. and Schutz, Howard G., "History of Food Acceptance Research in the US Army" (2003). US Army Research. 37.

https://digitalcommons.unl.edu/usarmyresearch/37

This Article is brought to you for free and open access by the U.S. Department of Defense at DigitalCommons@University of Nebraska - Lincoln. It has been accepted for inclusion in US Army Research by an authorized administrator of DigitalCommons@University of Nebraska - Lincoln. 


\title{
Appetite
}

Appetite 40 (2003) 199-216

www.elsevier.com/locate/appet

\section{History of food acceptance research in the US Army}

\author{
Herbert L. Meiselman ${ }^{\mathrm{a}, *}$, Howard G. Schutz ${ }^{\mathrm{b}}$ \\ ${ }^{\mathrm{a}}$ US Army Natick Soldier Center, Natick, MA 01760-5020, USA \\ ${ }^{\mathrm{b}}$ University of California Davis, Davis, CA 95616, USA
}

Received 12 January 2002; revised 22 February 2002; accepted 27 December 2002

\begin{abstract}
The history of food acceptance research by the US Army in Chicago and Natick is reviewed. The review covers the staff of the two research centers, the research programs, and the significant accomplishments of the Army laboratories from the 1940s to the present. Accomplishments begin with the development of the nine-point hedonic scale, and the development of the first Food Acceptance Laboratory. Further accomplishments include studies of sensory psychophysics, food preferences, food choice and food intake. The laboratories designed methods and conducted research on the role of consumer variables in the acceptance of food products and food service systems. Recent work has focused on new scaling approaches, the role of contextual factors and the importance of product expectations. Throughout the period of the review, the Army research has examined the relationship of laboratory acceptance to field acceptance, and the relationship of acceptance to intake.
\end{abstract}

Published by Elsevier Science Ltd.

Keywords: Hedonic scale; Food acceptance; Food preference; Longterm feeding; Field studies; Context; Expectations; Sensory

\section{Introduction}

We have undertaken a review of the history of food acceptance research in the US Army and its impact on food acceptance research in general for a number of reasons. First, the two of us span over 50 years of working for and with the Army laboratories which originated the concept of food acceptance, and which have continued to research, develop and utilize food acceptance methods and theory. Howard Schutz worked in Chicago from 1951 to 1957; Herbert Meiselman worked at Natick from 1969 to the present. In addition, Howard Schutz worked as a contractor with Natick in the 1970s, and has worked as a summer Visiting Scientist at Natick from 1993 to the present. We will present the review chronologically, but not year-byyear. The work was not evenly distributed over this period of time, and during some years relatively less was accomplished. Also, there was a major disruption when the laboratory moved from Chicago to Natick, and we can report relatively little from this period.

\footnotetext{
* Corresponding author. Tel.: + 1-508-233-4522; fax: + 1-508-233-5527.

E-mail address: herbert.1.meiselman@us.army.mil (H.L. Meiselman).
}

This review will cover the first 56 years of food acceptance research by the US Army. However, we cannot be exhaustive because literally hundreds of people have worked at the Quartermaster Food and Container Institute (QMFCI) in Chicago and then the US Army Natick Laboratories in Natick. These people conducted hundreds of research projects and produced thousands of papers and reports. We will include representative papers and summary reports. Both Chicago and Natick had many employees working on a broad range of research and engineering programs. The Chicago laboratory was the QMFCI, and, therefore, was entirely oriented around food. Natick is an equipment laboratory that produces individual equipment for soldiers and other service personnel, and food is one of the research and development programs.

\section{The Quartermaster Food and Container Institute (QMFCI) of the Armed Forces, Chicago, Illinois, USA}

Formation of the Food Acceptance Branch 1945-49

In 1944, the Army Quartermaster Subsistence Research and Development Laboratory in Chicago, Illinois, 
established a Food Acceptance Research Branch for the purpose of providing the reliable and valid prediction of the acceptability of various food products and rations. Major Virgil Wodicka, who was assigned to the Quartermaster, and Major George Gellman, who eventually became Director of the QMFCI, recognized the importance of food acceptance to the overall mission of the Army. It was with this orientation that they visited commercial sensory laboratories such as at Seagrams in 1945. They eventually offered the position of Chief of the newly formed Food Acceptance Research Branch to W. Franklin Dove, a biological researcher at the University of Maine, who had written articles relative to human preferences.

The Committee on Food Research, which was formed as an advisory committee to the overall laboratory, sponsored what probably was the first food acceptance conference in December 1945, at which noted researchers from across the country presented papers that widely covered the area of food acceptance in the Army. The food acceptance program as presented at this conference had four main divisions: food habit studies, psycho-physiological studies, organoleptic studies and statistical theory (Committee on Food Research, 1945).

The first addition of professional staff to the Food Acceptance Research Branch occurred in 1948 when Rosaltha Sanders, a physiologist, joined Dove. Other members of the Food Acceptance staff during this period were: Jackie Leavitt, food technologist; Catherine Walliker, food and nutrition specialist; Ruth Epstein, statistician; and Donald Washburn, research analyst.

The food acceptance testing conducted internally was a cross between expert judgments and trained panels, and consumer judgments for the purpose of developing quality specifications for Army rations. The affective methods utilized were almost entirely of the paired-preference nature. Dove published a paper in 1947 in Food Technology entitled 'Food Acceptability-Its Determination and Evaluation' (Dove, 1947). This reference is one that those interested in the very early methods will find useful. The use of a difference-preference test is listed as one of the primary testing methods. In this test, differences are first determined and then the different and the same samples are rated for which one is preferred. It was somewhere in the 1945-1947 period that the first panel facility with booths was constructed, which is described in the 1947 paper by Dove. At that time, this facility represented one of the most sophisticated for food product sensory evaluation in the United States.

The primary external research activity, entitled 'Appetite Levels of Food Consumption,' was related to monitoring a large number of regional food habit studies conducted by universities across the country (Dove, 1943). This involved data collection on regional national likes and dislikes for a national list of foods. Information was obtained on preference using a paired preference technique, the preferred method of preparation, mode of serving, preferred varieties, brands, or kinds, and the favorable and unfavorable combinations of psycho-physiological effects attributed to each.

\section{The Food Acceptance Branch 1949-1962: staff}

In 1949, there was a major administrative change in the Food Acceptance Research Branch and Dove and Sanders left the Institute (Table 1). Dove took a position at the University of Illinois and developed an affective scale utilizing Dove units that, to the best of our knowledge, never received wide acceptance in the field. In 1949 David Peryam was hired to head the Food Acceptance Research Branch, coming from the Seagram Laboratories where he had been in charge of the quality control program. David Peryam was a psychologist and his hiring began the era, in the Food and Container Institute and perhaps in the field of food acceptance in general, of the role of psychologists in food acceptance research. Certainly this is true of applied food acceptance research; however, researchers in universities at this time were doing basic research in the areas of taste, olfaction and food preferences. David Peryam was joined shortly by another psychologist from Seagrams, Norman Girardot.

David Peryam and Norman Girardot were joined in subsequent years by a large number of psychologists and professionals in related disciplines to build what, at that time, was the largest collection in the world of researchers working on both theoretical and applied areas in food acceptance, appetite, and hunger. In early 1951, Frank Pilgrim, a psychologist and chemist from the University of Pittsburgh joined the Branch to head up the psychophysiological area, followed shortly by the junior author who had just finished all of his coursework for the MS at Illinois Institute of Technology in Experimental and Physiological Psychology. In 1952, they were joined by

Table 1

Chicago personnel working in food acceptance

Arranged in alphabetical order, with degree and university where available, and approximate dates of service at Chicago

Joseph Bradley (PhD, Pennsylvania State University), 1953-55

Franklin Dove (PhD), 1945-49 d

Jan Eindhoven (MS, University of Hawaii), 1952-63

Norman Girardot (MS), 1950-53 d

Joseph Kamen (PhD, University of Illinois), 1955-64

Beverly Kroll 1953-64

Donald Paul (PhD, Illinois Institute of Technology), 1956-57

David Peryam (PhD, Illinois Institute of Technology), 1949-64 d

Frank Pilgrim (PhD, University of Pittsburgh), 1951-62 d

Elsie V. Raffensberger (MA, New School of Political and Social Research), 1954-56

Rosaltha Sanders (PhD), 1946-48 d

Howard Schutz (PhD, Illinois Institute of Technology), 1951-57

Richard Seaton (PhD, London School of Economics), 1955-57

Verona W. Swartz (MS, University of Chicago), 1949-51

d-Deceased. 
Richard Seaton, a social psychologist, Joseph Bradley, a marketing oriented psychologist, and Jan Eindhoven, a survey psychologist, and Donald Paull and Joseph Kamenetzky (Kamen) who were military personnel as well as psychologists. Joseph Kamen, joined the Food Acceptance Research Branch as a civilian in 1957. Elsie Rafensberger, a food scientist who had worked in sensory evaluation in industry, joined the branch to head up the food acceptance testing laboratory activities and was assisted by Beverly Kroll in this operation. Ken Woods, John Haynes and Norman Guttman, from the Statistical Branch, made many contributions to the Food Acceptance Branch. They brought sophisticated statistics to bear on analyzing and solving problems. They were able to utilize what would later become standard methods of analysis in the study of food acceptance behavior, such as factor analysis, canonical and conjoint analysis.

\section{The Food Acceptance Branch 1949-62: External Contract Research Program}

Under the general direction of David Peryam and a National Research Council Advisory committee, the external research program was continued and expanded from 1949 to 1963. This involved primarily the most distinguished psychologists in universities across the country working in the areas relating to food acceptance methodology including psycho-physiological aspects. Some of the earliest research contracts went to P.T. Young at the University of Illinois working on taste preferences in rats, and the distinguished anthropologist, Margaret Mead, working in the general area of food habits. The major external researchers are mentioned here with their institution, and their general area of research. David Peryam inherited a research program on olfaction by Goetzel at Kaiser Permanente. One of the most notable studies that we identified was related to Goetzel's hypothesis that the olfactory threshold changed in relationship to hunger, a finding that has not been supported by other researchers. Elliot Stellar, a physiological psychologist, and his students at the University of Pennsylvania, conducted some of the earliest basic research on gustatory neurophysiology. Lloyd Beidler from Florida State, a physiologist, also worked in this basic research area of taste physiology. Darrell Bock, Lyle Jones and L.L. Thurstone of the University of Chicago, conducted research related to measuring acceptance, and contributed heavily to the development of the nine-point hedonic scale (Jones, Peryam, $\&$ Thurstone, 1955). Carl Pfaffman and Harold Schlosberg from Brown conducted research on difference test measurement, and Noel Jones from UCLA had a contract involving the study of olfaction. Dean Foster from North Carolina also did olfactory research with humans in a large olfactorium that he had constructed. Paul Siegal from the University of Alabama studied monotony, and Ernest Furchtgott of the University of Tennessee contributed research in the area of taste. Purnell Benson from Drew University also was a contractor who conducted innovative optimization research. In the late 40 s and the early to late 50 s, this distinguished set of researchers and their students formed the basis of the major psychological and physiological contributions to food acceptance research. Bernice Polemis, a statistician, managed the contract that produced the first major food acceptance study of military personnel across the country, resulting in a landmark publication (Peryam, Polemis, Kamen, Eindhoven, \& Pilgrim, 1960). This research formed the basis of food preference surveys conducted at the Natick Laboratories in future years. In a National Research Academy conference on food acceptance methodology, several of these psychologists from universities as well as members of the Food Acceptance Branch produced a publication to which to this day is a source of basic information with regard to food acceptance methodology (Peryam, Pilgrim, \& Peterson, 1954).

\section{The Food Acceptance Branch 1949-62: The Internal Research Program}

Each of the professionals in the Food Acceptance Branch, acting as project officers, met with the various contractors mentioned earlier, both in their facilities and at the Institute. This provided for an informal advisory group of immeasurable value to the Institute. The second author finished the work for his master's degree while working at the Institute and because of the 'kitchen cabinet' advisory capability of all the contractors, decided to stay on at the Institute where he conducted his $\mathrm{PhD}$ research (Schutz \& Pilgrim, 1957a).

\section{Hedonic scale}

Perhaps the most lasting and visible output from the second era of the Food Acceptance Branch was the development of the nine-point hedonic scale. The development of the scale appears to have started at the Quartermaster Laboratory in 1949 as a project mainly involving Peryam and Norman Girardot (Peryam \& Girardot, 1952), and was improved during work with the University of Chicago beginning in 1951 involving Thurstone, Lyle Jones and Darrell Bock. Jones et al. (1955) used a large sample of soldiers to test the semantic meaning of 51 phrases (such as like extremely and like intensely). They developed and tested nine different scale types varying in number of categories, scale balance, equal number of positive and negative categories, and presence of a neutral category. The nine scales showed high reliability $(r=0.8-0.9)$. Longer scales tended to transmit more information. No particular advantage was seen for scales with a neutral point, or for scales with the same number of positive and negative categories. Peryam and Pilgrim (1957) discussed the use of the hedonic scale, indicating that many variations in the scale did not seem to have serious consequences; this paper is the most frequent reference for the scale, although it is not 
the first paper and does not detail many of the developmental considerations.

This scale has become one of the basic workhorses in food acceptance across the world, probably because it is one of the easiest, if not the easiest, scale for consumers to understand. It has been translated into many languages, not without problems, because words such as 'dislike' do not always translate easily. Another major criticism of the hedonic scale was that it did not have equal interval properties.

Schutz and Kamen along with a contractor, Schwerin, studied the ability of the hedonic scale to predict food choice and consumption. These studies found that about $50 \%$ of the variance in choice or consumption could be accounted for by hedonic mean scores, but that up to $75 \%$ could be accounted for if one looks at individual food groups rather than food items. Pilgrim and Kamen (1963) were able to improve on the predictability of the scale for consumption if one added such factors as satiety and the percentage of nutritional components such as carbohydrate. More recent analysis by Kees de Graaf of the relationship between acceptance and intake from Natick field testing of rations has yielded significant but moderate correlations, indicating that acceptance is an important factor, but not the only factor contributing to intake.

Peryam, Pilgrim, Schutz, Seaton, and Jan Eindhoven conducted a number of studies in which various aspects of the scale were elucidated. For example, the scale was found equally sensitive to monadic presentations and paired comparisons in differentiating the acceptance of foods; the scale demonstrated the role of contrast and convergence in acceptance; the scale was found useful to study unusual or novel foods; the scale was used to provide the first evidence that food combination acceptance could be predicted from individual food ratings (Eindhoven \& Peryam, 1960); and it was found that food names are rated more closely to their best preparation than their poorest.

\section{Sensory psychophysics}

Pilgrim, Schutz and Kamen conducted a number of studies in taste and odor psychophysics. The difference thresholds for the basic tastes were determined and revealed major differences in the Weber fractions and evidence for individual differences in sensitivity (Schutz \& Pilgrim, 1957a). It was found that MSG behaved in a fashion similar to sodium chloride rather than as a special new taste. The relative sweetness of a number of natural and synthetic sweeteners was measured using suprathreshold rather than absolute threshold measurements. This study made it clear that using absolute thresholds with real foods was generally inappropriate (Schutz \& Pilgrim, 1957b). The first systematic study of interactions of suprathreshold taste stimuli was conducted, and it was found that in most cases the effects were those of simple enhancement or masking.

A one-person olfactorium was constructed in which studies could be conducted in highly controlled ambient conditions. Studies were completed demonstrating that olfactory cross adaptation was most likely a central rather than a peripheral phenomenon, and a modern odor classification system developed based on the rating of odor attributes.

\section{Psychophysiology}

During this second era under David Peryam, the Food Acceptance Branch testing facilities were remodeled, and a psycho-physiological laboratory was set up under Frank Pilgrim and Howard Schutz. The self-selection of nutrients by rats after starvation revealed an increase in the selection and consumption of fat that persisted until a normal weight was reached. The role of insulin in appetite was studied in rats with results that were not supportive of the then current theory of insulin causing increased appetite.

A unique study on satiety was conducted using a human and rat model that demonstrated that the influence of consuming a large pre-meal portion of food on subsequent meal consumption was primarily a function of how well it was liked rather than whether or not fresh or dehydrated potatoes were consumed.

The spirit of research openness in the Food Acceptance Branch led to some innovative, if not successful, attempts at obtaining instrumental measures of acceptance by Schutz and Pilgrim. In one attempt, subjects were attached to a polygraph and ate a number of foods. Subjects responded differentially to the foods, giving different readings for poorly liked and well-liked foods as compared to foods that were near the middle of the hedonic scale, but we could not tell whether they were liked or disliked! Score one for the hedonic scale.

Schutz cooperated in research with Doris Calloway who was a nutritionist with the Medical Nutrition group stationed at the Chicago site. They investigated the role of reserpine in enhancing appetite in rats. The results indicated very little evidence of an appetite enhancing effect.

The area of monotony in foods was investigated internally by Schutz, Pilgrim and Kamen and under contract with Paul Siegel of the University of Alabama. These efforts were among the first, if not the first, systematic and scientific studies of monotony (Schutz \& Pilgrim, 1958; Siegal \& Pilgrim, 1958). Because many Army rations are served in a manner that might produce monotony and lead to reduced food consumption, it was an important area for study. Among the results of these studies was the demonstration that monotony effects were greatest for disliked foods and least for bland foods.

\section{Sensory evaluation}

Many of the practical aspects of sensory evaluation were first investigated by the QMFCI. Such factors as the number of samples for preference tests (12 maximum), innovative difference testing (duo-trio), contrast and convergence 
effects and reliability of sensory tests were studied (Peryam, 1958).

Because the purpose of the acceptance testing in the QMF\&CI was to predict soldiers' attitudes, a study was conducted by Peryam relating civilian panelist ratings at the Institute to soldiers' ratings in the field for a number of foods. It was found that the civilian ratings were very good predictors of soldiers ratings (Peryam \& Haynes, 1957). With the increased emphasis on field-testing at Natick, this general area continued to receive interest.

One noteworthy collaborative effort with other groups at the QMFCI was in the area of irradiated foods. Many acceptance panels were conducted to determine the influence of a wide variety of processing conditions for many foods on acceptance. The use of inert atmospheres such as nitrogen and irradiating under cold conditions were found to markedly improve acceptance. The interest in acceptance of irradiated foods continued at Natick.

Based on the experiences in the Acceptance Branch and discussions among the professional staff, Pilgrim published a paper presenting a descriptive model of the factors contributing to food acceptance that is still widely cited in the food acceptance and choice literature (Pilgrim, 1957).

The members of the Food Acceptance Branch worked closely with commodity branches within the Institute producing a variety of quality specifications for rations, and developed some of the basic quality control methodology that became part of standard procedures in industry. It was during this period that the difference-preference test was found faulty because of a negative bias introduced by the odd sample, and to this day is a procedure considered inappropriate in sensory evaluation.

Most of the visitors to the Food and Container Institute's Food Acceptance Branch were the various contractors mentioned earlier, but there were a few people who visited from other institutions in the United States and internationally. Birger Drake from the Swedish Institute of Food Technology visited and studied the role of sounds of foods being chewed in acceptance, and Roland Harper, a distinguished psychologist from the University of Reading, England, worked in a variety of areas including odor and food acceptance research.

\section{End of the Chicago period}

During the 1948-1957 period all internal researchers we have mentioned, joined, and many left the institute. Departure in the earlier years was due to opportunities to apply their research capabilities elsewhere, and in the last 3-4 years was due in part to the impending move of the laboratory from Chicago to Natick, Massachusetts. When they left, they left with a piece of the joint experience and orientation developed at the Food Acceptance Research Branch, and in some way helped to spread the basic philosophy and methods developed there during this period of time. David Peryam and Beverly Kroll formed their own sensory evaluation consumer research firm that exists today as one of the oldest and most well known in the area of commercial sensory evaluation. Norman Girardot joined the Coca-Cola Company where he headed up their consumer field research for many years. Frank Pilgrim became a researcher for the Pillsbury Corporation in Minneapolis, and Joe Bradley headed up market research for the Lipton Corporation. Dick Seton went on to the University of British Columbia in the school of architecture, and Joe Kamen became a marketing professor at the University of Indiana, Gary branch. Howard Schutz, the second author, left to become a human factors psychologist at Battelle Memorial Institute in Columbus, and left that position for industry as Associate Director of Research at Hunt-Wesson Foods, where he reported to Virgil Wodicka who had been the Director of the food laboratories at the QMFCI. Schutz later accepted a position as Professor at the University of California, Davis. Jan Eindhoven took a position in the federal government.

\section{The transition from Chicago to Natick}

Natick Laboratories was opened in 1954 as the Quartermaster Research and Development Center. The decision to move the food research program from Chicago to Natick was made well before the actual move, but the food research program actually moved to Natick in August 1963. Before this time, all of the behavioral research at Natick Laboratories was human factors/human engineering in support of the existing research and development programs in clothing and other materiel. This human factors group was headed by Ralph Dusek who eventually moved to the Surgeon General's Laboratory, the US Army Research Institute of Environmental Medicine co-located at Natick that had opened in 1961. The Surgeon General is the medical organization of the Army, and this organization specializes in the effects of environmental factors (temperature and altitude) on human performance and health. During the transition from Chicago to Natick, Joe Kamen from Chicago visited Ralph Dusek at Natick to help with the transfer. The accumulated information from Chicago was also transferred to Natick.

Beginning in 1966, Harry Jacobs, who had been recruited from The University of Illinois, began a program in behavioral sciences, with a strong emphasis on food. Jacobs was hired for the new job as Chief of Behavioral Sciences, and began working at Natick in 1966. Dr Jacobs hired Linda Bartoshuk of Brown University to begin with him. Jacobs and Bartoshuk had different but compatible interests. Jacobs was interested in basic animal studies of appetite regulation. Bartoshuk was interested in basic human studies of taste processes and taste perception.

Between 1963 and 1966 was a period of transition. The food acceptance laboratory was moved from Chicago into new laboratory space with a large central kitchen and eleven 
individual testing booths surrounding a large kitchen. In 1965, an official Technical Report (Number EPT-5) was published on 'Food Acceptance and Preference Research: An Annotated Bibliography'. This report was prepared by three Natick staff in the new Acceptance Laboratory (Bell, Oshinsky, \& Wolfson, 1965), with the assistance of former Chicago employees (Eindhoven, Kamen, McCoy, Peryam, Pilgrim and Schutz). This was the only published report coauthored by the two organizations.

When the research and development activities of the Food and Container Institute in Chicago were moved to Natick, Massachusetts, some activities such as dietetic services and nutrition remained in Chicago. The dietetic services were eventually moved to Fort Lee, Virginia, and the Nutrition research program was moved to Colorado, then San Francisco, and eventually to Natick to the Surgeon General's laboratory. Other chapters in this series present aspects of the US Army's Nutrition Research Program.

\section{Natick Laboratories, Natick, Massachusetts, USA}

The early years of The Behavioral Sciences Division under Jacobs turned out to be critical for the future direction of the laboratory because of the early decisions on personnel and programs. The program that evolved over the early years at Natick resulted from the interaction of four factors: the placement of Behavioral Sciences within Natick, the needs of Natick and the US Army, the professional goals of the key scientific personnel at Natick, and the available resources.

Natick has always had several different product laboratories related to food, clothing, shelters, and airdrop equipment. In addition there has been a basic research laboratory that supports all of the product laboratories. It was extremely important to the future of the Natick group that Behavioral Sciences was placed within the basic science laboratory. This attracted scientific staff rather than engineering staff, and permitted them to conduct basic research, which was part of the science laboratory mission. Within the product laboratories, there would have been much greater applied pressure. Some time later, Natick started a Systems Analysis Office, which had another great impact on Behavioral Sciences, which will be covered below.

The needs of Natick and the US Army have had a major role in directing the Natick program in food acceptance. But the needs of the Army had to be interpreted by a series of research managers locally in Natick and centrally in Washington. The philosophy of how to support product development changed both gradually, and sometimes dramatically, over the years. In the early years at Natick, there was a great emphasis on basic research, and the environment was similar to a research institute. Since that time there has been a gradual increase in applied orientation, and in specifying how the research will eventually be used.
Throughout the period there has been a general support of publishing by Natick scientists. Natick has none of the prohibition of publishing such as exists in industry and none of the pressure to publish such as exists in academia. At Natick, people who want to publish can do so, and are supported to do so. At the higher levels of personnel promotion as a scientist, extensive publishing is required. Publishing at Natick is not as important as the project itself; publication is not an end in itself. However, along with the increased applied orientation at Natick has come a greater realization that publication is basically an endorsement of peer review and approval.

The Natick program has evolved in part because of the influence of the key researchers. Two areas of specialty were sensory psychophysics resulting from the work of Bartoshuk, Moskowitz, Meiselman, Cardello and Popper, and many visiting sensory scientists, and appetite regulation and food habits, resulting from the work of Jacobs, Hirsch, Kramer, Maller, Engell, Bell and others.

Finally, the Natick program evolved in part because of the resources available. The cost of Army field rations alone is over $\$ 100,000,000$ per year, and the cost of feeding the Army annually is much greater. Further, the problems of feeding the Army are a serious logistics burden that can limit their ability to move and to fight. Therefore, the relatively small cost of the food research program is a tiny fraction of the cost of the system that it supports. This program has been well supported at Natick for 35 years. Also the nature of Army problems often requires expensive efforts to solve them. A field study might be required to compare one ration to another, and the field study might require obtaining data from 100 troops three times per day for 10 days in several different locations. Natick has had the resources to do many of the types of studies that would have been difficult or impossible elsewhere.

\section{Staff}

\section{Permanent staff}

In the early years at Natick, some of the key personnel at Natick were added in pairs, due to Dr Jacobs' ability to maximize recruiting when a personnel space became available. The first two scientists in the new group were Harry Jacobs and Linda Bartoshuk (Table 2). As noted, Jacobs' interest was in animal studies of appetite regulation. He had worked with Adolph at the University of Rochester. Bartoshuk's interest was in human chemical senses especially taste, and she had studied with Carl Pfaffmann at Brown University. Naomi Oshinsky and Joel Sidel were hired to manage the Acceptance Laboratory. Two additional scientists were added in 1969, Howard Moskowitz from S.S. Stevens' psychophysics laboratory at Harvard, and Herbert Meiselman from Bruce Halpern's taste laboratory at Cornell. Meiselman received his doctorate with Ernest Dzendolet at The University of Massachusetts, and both Halpern and Dzendolet had worked in Pfaffmann's 
Table 2

Natick personnel in food acceptance and food habits, 1965-2002

Arranged in alphabetical order, with degree and university where available, and approximate dates of service at Natick

Lynn Abusambra (PhD, University of Notre Dame), 1985-87

Simone Adams (DPH, U.C. Berkeley), 1990-95

Linda M. Bartoshuk (PhD, Brown University), 1965-71

Barbara L. Bell (BS, Framingham State College), 1965-98

Richard Bell (ScD, Harvard University), 1990-present

Captain Douglas Bloomquist (MS, Bucknell University), 1969-71

Harry E. Bose (PhD, Northern Illinois University), 1972-73 d

Captain Lawrence G. Branch (PhD, Lloyola University), 1972-75

Armand V. Cardello (PhD, University of Massachusetts), 1977-present

Captain Eugene Chao (MS, Florida State University), 1977-79

Elizabeth Comstock (PhD, University of Massachusetts), 1979-82

Barbara Edelman-Lewis (PhD, Clark University), 1976-85

Captain F. Thomas Eggemeier (PhD, Ohio State University), 1972-75

Dianne Engell (PhD, Clark University), 1982-96

Captain R. Curtis Graeber (PhD, University of Virginia), 1972-75

Edward Hirsch (PhD, Rutgers University), 1981-present

Captain Louis A. Hoff (PhD, University of Georgia), 1966-69

Harry L. Jacobs (PhD, Cornell University), 1966-86

F. Matthew Kramer (PhD, Penn State University), 1988-present

Robert A. Kluter (MS, Ohio State University), 1972-present

Laurie Lester (PhD, Dartmouth University), 1987-90

Owen Maller (PhD, University of Illinois), 1976-90

Herbert L. Meiselman (PhD, University of Massachusetts, 1969-present

Howard R. Moskowitz (PhD, Harvard University), 1969-76

Naomi Oshinsky, 1962-68

Captain Thomas L. Nichols (PhD, University of Texas), 1966-76

Richard Popper (PhD, Columbia University), 1983-89

Captain Charles Salter (PhD; ScD, Harvard University), 1982-86

Barbara Sandick (PhD, Brandeis University), 1979-84

Joel L. Sidel, (MA, Northeastern University), 1965-1969

Stephen Siegel (PhD, Brown University), 1985-86

Captain James R. Siebold (PhD, University of Iowa), 1973-76 d

Captain Gerard Smits (PhD), 1981-84

Captain Edwin R. Smutz (PhD, University of Arizona), 1972-75

Captain Earl S. Stein (PhD, University of New Hampshire), 1974-77

Captain Robert Stretch (PhD), 1984-86

Captain J. Bradley Swanson (PhD, Purdue University), 1972-75

Lawrence E. Symington (PhD, UC Santa Barbara), 1972-92

Day Waterman (MS, Connecticut College), 1972-78

Captain William K. Wilkinson (PhD, Yale University), 1976-80

Captain Kerry W. Wyant (PhD, University of Oklahoma, 1977-80

laboratory at Brown. Moskowitz and Meiselman were interested in human sensory testing and sensory processes. Both of them had applied interests as well. Their applied interests had a major impact on Natick and on their careers. In the late 1970s, Armand Cardello joined the group, also from Dzendolet's laboratory at The University of Massachusetts, and Owen Maller left the Monell Chemical Senses Center in Philadelphia to join Natick. Cardello was also interested in human studies of sensory perception especially taste, and Maller was interested in sensory and physiological variables involved in human eating. Robert Kluter joined the acceptance laboratory staff in 1972, coming from HuntWesson Foods and earlier from the Battelle Laboratory in Columbus, Ohio; at both places he had worked with Howard Schutz.
Another group of scientists joined Natick in the 1980s. In 1981, Edward Hirsch, who had worked with George Collier at Rutgers University, left Mount Holyoke College to join Natick. Hirsch had been a Visiting Scientist at Natick in the early 1970s, working on animal models of eating. Dianne Engell joined Natick in 1982 from Clark University. Richard Popper came from Eugene Galanter's laboratory at Columbia University in 1983. Laurie Lester began working at Natick in 1987. Matthew Kramer joined Natick in 1988 from A.J. Stunkard's laboratory at The University of Pennsylvania. Kramer and Maller were both trained clinical psychologists. Barbara Edelman-Lewis came to Natick from Rutgers, and then obtained her doctorate at Clark University. Richard Bell began at Natick in 1990, having left a sensory evaluation position at Gorton's of Gloucester.

\section{Military scientists}

All of the above scientists were permanent staff members of Natick. In addition there was a large group of military officers, who were scientists, and who worked at Natick for 2-3 years. The military officers included Lawrence Symington, Lawrence Branch, Douglas Bloomquist, James Siebold, Richard Johnson, Kerry Wyant, J. Bradley Swanson, R. Curtis Graeber, Earl Stein, Edwin Smootz, William Wilkinson, Gerard Smits, Engene chao and Charles Salter. Many of these scientists went on to work in other government and academic settings. Graeber continued his research in chronobiology; and Smootz eventually headed up all of the applied human factors field work in the US Army. The military officer scientist-program ended at Natick in 1985. The military officers were especially valuable in conducting the large-scale field surveys, because they had the training of an experimental psychologist and the skills of an Army officer.

\section{Visiting Scientists}

There was also a group of Visiting Scientists who worked at Natick for periods of several months to several years (Table 3). The Visiting Scientists took the place of the contract program in Chicago, in that the visitors greatly broadened the Natick work, perspective and output. Most of the Visiting Scientists worked at Natick during the period 1966-1976. There was a drop in Visiting Scientists during the 1980s, and another group of Visiting Scientists worked at Natick during the 1990s. The earlier group included people interested in sensory processes (Akira Adachi from Japan, Donald Ganchrow, Erick von Sydow from Sweden, Linda Bartoshuk, Bruce Halpern, Martha Teghtsoonian, David Stevens), appetite (Zvi Glick, Kamal and Sheel Sharma from India, Jin Soon Ju from Korea, C. Wayne Simpson, Edward Hirsch, Emil Becker), and food habits (Robert Gentile, Antonia Gerald, Eleanor Eckstein, Richard Moon).

In the 1980s Visiting Scientists included Harry Lawless, Claire Murphy, James Kuznicki and Einar Risvik from Norway in sensory science. In the 1990s there was another 
Table 3

Visiting scientists and fellows

Arranged in alphabetical order with home institutions (and country if not USA) and approximate years of visit

Akira Adachi (Osaka University, Japan), 1967-69

Linda M. Bartoshuk (John B. Pierce Foundation), 1973

Emil Becker (City University of New York), 1975-76

Frank R. Dastoli (State University of New York at Syracuse), 1969-72

Cees de Graaf (Wageningen University, The Netherlands), 1997, 1999

Eleanor Eckstein

Donald Ganchrow (Duke University), 1969

Robert Gentile (Clark University), 1967-71

Antonia Gerald (Harvard University), 1969

Zvi Glick (University of California at Berkeley), 1969

Molly Hall (Yale University), 1973

Bruce P. Halpern (Cornell University), 1973-74

Robert Harvey (Worcester Polytechnic Institute), 1968

Samuel Hill (Russell Sage College), 1979

Edward Hirsch (Rutgers University), 1972-74

Sara Jaeger (Reading University, UK), 2001, 2002

Jim Soon Ju (Woo Sok University Medical School, Seoul, Korea), 1971

James T. Kuznicki (State University of New York), 1976-77

Harry T. Lawless (Brown University), 1978-79, 1996

Lawrence Liebling (Cornell University), 1973

David Marshall (University of Edinburgh, UK), 1997, 2000

Donald McBurney (University of Pittsburgh), 1969

Richard Moon (City University of New York), 1975-76

Claire Murphy (University of Massachusetts), 1977-80

Stelios Nicolaidis (College de France, France), 1972

Patricia Pliner (University of Toronto, Canada), 2002

Einar Risvik (Norwegian Food Research Institute, Norway), 1985

William J. Rodier III (University of Virginia), 1973

Frederick Miles Sawyer (University of Massachusetts), 1979-89

Howard Schutz (University of California Davis), 1974, 1993-present

Kamal Sharma (St Johns Medical College, Bangalore, India), 1969-70

Sheel Dua-Sharma (St Johns Medical College, Bangalore, India), 1969-70,

72-72

C. Wayne Simpson (UC Santa Barbara), 1970-71

David A. Stevens (Clark University), 1979-81

Martha Teghtsoonian (Smith College), 1975-78

Ann Tennison (State University of New York at Albany), 1987

Yehoshua Tsal (University of Massachusetts Boston), 1979

Hely Tuorila (University of Helsinki, Finland), 1993-94, 1996-7, 2000

Alan H. Wayler (Veterans Administration), 1979

stream of visitors. Hely Tuorila (Finland) worked on cognitive variables in sensory evaluation, Cees de Graaf (The Netherlands) worked on food habits and nutrition, and David Marshall (Scotland) visited several times to work on consumer and market research aspects of product evaluation. Harry Lawless also visited for a summer. In 20012002 Sara Jaeger (New Zealand) and Patricia Pliner (Canada) visited Natick. In 1994, Howard Schutz began working at Natick every summer.

The final group that should be mentioned is the large group of assistants and statisticians that supported the Natick group over the years. The large productivity of the Natick group can be traced in part to the fact that their work was well supported with assistants. This allowed the scientists to undertake the types of studies that cannot be conducted without adequate manpower. These include the labor-intensive field tests for which Natick became well known. Some of these studies required a staff of 20-30 people in the field for weeks.

\section{Careers after Natick}

Just as with the Chicago staff, the eventual destinations and careers of many of the Natick alumni are as interesting as their time at Natick. 'Natick graduates' went on to prominent positions in government, academia, research institutes, and industry. Many of these people stayed in, and contributed to the field. In this sense, Natick was not only a source of research but also a source of people who affected the field of food acceptance after their time at Natick. Linda Bartoshuk remained in the study of basic sensory science, first at the John Pierce Foundation and then at Yale University. Joel Sidel left Natick to eventually form Tragon Inc., a major consumer research and sensory testing firm. Naomi Oshinsky left Natick for a career in food testing. Howard Moskowitz left Natick to work in several market research consulting firms, eventually forming his own firm, MJI Inc. Richard Popper went to Ocean Spray Cranberries, and then to Peryam and Kroll. Dianne Engell went to Pizza Hut, Inc.

\section{National Academy of Sciences Panel}

At Natick, a new mechanism was developed to provide for the continuity of the involvement of outside academic personnel who had worked for the Chicago laboratory under contract. Many of these same people, and some new people, were asked to sit on a series of review committees managed by the National Academy of Sciences/National Research Council (NAS/NRC). An overall National Research Council Advisory Board on Military Personnel Supplies contained a subcommittee dealing with the Behavioral Sciences Program at Natick. The members of this committee evolved over the years to represent the new interests of Natick in food service systems, food habits, and human performance in addition to the traditional topics of flavor and appetite. The committee meetings provided opportunities for the Natick scientists to meet with the committee scientists to discuss their programs. The committees operated until the 1980s when the entire NAS/NRC committee structure at Natick was abandoned because of budget constraints.

\section{The research program}

\section{The Early Basic Research Program}

The early food research program at Natick was basic research aimed at animal studies of appetite regulation and human and animal studies of chemical senses. In the sensory area, this era produced an enormous output of scientific work and publications. Bartoshuk did pioneering studies in several areas including psychophysical studies of basic taste phenomena such as water taste and taste mixtures. She also undertook studies of naturally occurring taste modifiers flavor modifiers and enhancers. Moskowitz conducted a 
series of studies on the basic psychophysics of taste and smell. And Meiselman, worked on methodological phenomena, that affected taste psychophysics. Dr Jacobs' laboratory, working mainly through Visiting Scientists, worked on animal studies of appetite. The work of these permanent staff members was augmented by the work of the large number of Visiting Scientists, and the fact that many of the staff had associations with universities. Meiselman carried out a long-term collaboration with Bruce Halpern at Cornell, and Moskowitz worked with academics such as Phipps Arabie and Joseph Balintfy.

\section{Psychophysical studies}

Psychophysical studies began soon after the move of the Food Program from Chicago because Bartoshuk was one of the early employees. Bartoshuk worked exclusively in the sense of taste. She conducted a number of now-classical studies of taste description and quantification involving water taste and taste mixtures. These studies demonstrated that tastes are not as simple as salt and sugar (salty and sweet), because tastes are dependent on what precedes the stimulus, and on what is mixed with the stimulus. One of the keys to understanding how taste operates when actually eating is an understanding of the basic phenomena of water taste and taste mixtures, because food components are almost never consumed alone.

Bartoshuk also conducted studies on a number of taste modifiers and enhancers, seeking clues to the mechanisms for basic tastes. She formed a contact with Dr Dokasi, a botanist in Africa, who had worked with miracle fruit and other products. At Natick, she worked with George Dateo, an organic chemist who aided with preparation of the taste modifier Gymnema sylvestre that has anti-sweet properties. Both she and Meiselman, who also became involved in the taste modification research, worked with Robert Harvey and Frank Dastoli, who later set up a company to commercialize miracle fruit (Synsepalum dulcificum) that converts sour taste to sweet. The company ('Mirlin') actually got as far as obtaining huge growing fields for the plant in Central America before the Food and Drug Administration decided to not classify miracle fruit as Generally Regarded as Safe, and, therefore, required expensive and lengthy toxicity trials. At that point, the company ceased operation.

Howard Moskowitz joined Natick after completing his doctorate with S.S. Stevens at Harvard University. For years after this, the psychophysicists at Natick joined others in the Boston area for a monthly meeting at Professor Stevens' laboratory. Moskowitz conducted psychophysical studies of both taste and smell at Natick. Bartoshuk's studies were oriented toward uncovering receptor mechanisms, and hence, she conducted controlled studies of gustatory phenomena in a relatively small number of subjects. Moskowitz's studies were aimed at discovering the relationships among variables, and hence he used larger numbers of subjects in less rigidly controlled studies. Bartoshuk's work was more mechanistic and Moskowitz's more descriptive. Moskowitz was seeking the basis for describing the mathematical relationships among sensory variables. Further, Bartoshuk was mainly interested in taste perception (intensity and description), while Moskowitz was interested in taste and smell perception and taste and smell hedonics. Moskowitz's interest in hedonics was a predictor of his later interest in the applied and commercial aspects of sensory work.

Moskowitz conducted a number of large descriptive studies of taste, smell, and more complex phenomena. Beginning in 1970, he published a long series of papers on magnitude estimation of basic taste and texture qualities including sweetness (including both sugars and artificial sweeteners), sourness, viscosity, fluidity, hardness and crunchiness, and temperature. He then began to develop psychophysical models of more complex phenomena dealing with direct estimation of hedonics and food acceptability, including the notions of subjective ideals and optimization. He produced papers dealing with the complex topics of taste mixtures, odor mixtures, odor identification, and odor similarities. His early papers also took him into areas of economics and food habits, where he dealt with the practical problems of using food preference data to design menu combinations and overall menu evaluation. Moskowitz's prolific writing style, which would continue for the next 30 years, was evident at this early stage of his career. He wrote dozens of original research papers, and an equal number of reviews with broad coverage of topics such as psychophysics, sweetness, texture, acceptability, ratio scaling (magnitude estimation), and sensory measurement.

Shortly after Moskowitz arrived at Natick, Herbert Meiselman joined, completing the group of three psychophysicists. Meiselman had completed his doctorate with Ernest Dzendolet, who had studied with von Bekesy and Pfaffmann, and had worked with Bruce Halpern on a postdoctoral fellowship. Meiselman was especially interested in sensory methodology, and many of his taste psychophysical studies were aimed at determining how the method contributed to the results obtained. Meiselman studied the effect of flow rate, the phenomenon of sourbitter confusion, and the incompleteness of sensory adaptation. Meiselman maintained an interest in taste adaptation throughout much of his career later working with Bruce Halpern on alternative means of studying adaptation. While Bartoshuk studied basic taste processes, and Moskowitz studied the psychophysical mathematics of taste and smell, Meiselman (1981) studied methodological issues in taste research using the same direct scaling techniques as Bartoshuk and Moskowitz.

The outcome of Meiselman's methodological research was realized in his collaborative research with Bruce Halpern (Halpern \& Meiselman, 1980). Meiselman used an apparatus designed by Halpern that presented pulsed trains of stimuli to the tongue. This alternation mimicked the actual conditions within the mouth, where stimuli are repeatedly exposed, rather than continuously exposed, to 
tongue receptors. When salt was flowed continuously over the tongue, the experimenters observed adaptation, but under the salt-water alternation, they observed no adaptation and even a hint of enhancement. They concluded that sensory adaptation is not a serious problem in real eating.

In the late 1970s, Howard Moskowitz left Natick to begin a long career in industry, and Armand Cardello filled his niche in the psychophysical area at Natick. Cardello combined the basic receptor interests of Bartoshuk with the more applied interests of Moskowitz and Meiselman that pulled him toward hedonics. He continued his work on single taste papilla stimulation, while beginning work on relative sweetness in real food systems and the psychophysics of food texture. During this time, Natick also had several Visiting Scientists working in taste and smell psychophysics, Harry Lawless, Claire Murphy and Martha Teghtsoonian. The period from the late 1960s through the late 1970s was the main period of basic and applied psychophysical research on taste, smell and texture at Natick. Of the original Natick permanent staff involved in basic psychophysical research, only Bartoshuk maintained that interest throughout her career.

\section{Food systems studies}

Beginning in 1971 the Operations Research and Systems Analysis Office began systems studies of military food service systems, and called upon the behavioral scientists to assist. The first support work involved food preference surveys aimed at gathering data on which to base menus for experimental military feeding systems. Instead of using the traditional means of collecting food preference data, namely the nine-point hedonic scale developed at Chicago, Meiselman combined both hedonic scaling and preferred frequency scaling. In addition, Moskowitz worked on the math-modeling of menu preferences, using time preference modeling and compatibility modeling. Both Meiselman and Moskowitz used their backgrounds in sensory psychophysics and evaluation, and applied them to the new task.

In addition to food preference studies leading to menu design, the planning of military feeding systems required extensive data on customer attitudes, on food service personnel attitudes, and on the human factors of military food service equipment and kitchens. A number of behavioral scientists undertook these areas, and became experts over the course of numerous systems studies. The first systems study was conducted in 1971-72 for the Army at Fort Lewis, Washington, and involved the consolidation of hundreds of small dining facilities into a smaller number of large facilities (Branch \& Meiselman, 1972; Kiess, Swanson, \& Johnson, 1972). This process threatened the very fabric of military units, since feeding had always been done at a company level, giving the company commander responsibility for and control of food for his men.

The next systems study was done for the Air Force, at Travis Air Force Base in California. The Air Force already fed the airmen in large consolidated dining halls, so the focus of this study was different from that of the Army. This was followed by a Navy study, which added the element of feeding aboard ships as well as in fixed land facilities. To accomplish this, the Natick researchers flew to Europe and boarded aircraft carriers in the Mediterranean, living onboard with the ship's crew. Working in a Navy ship is very different than working in a fixed Army base. The ship is the seaman's home. The Navy experience demonstrated the role of food in a daily schedule. Food and meals was one of the important markers in the daily organization of life onboard ship. The problems encountered on the ships were also different; the main problem was the very long lines which the slow food service produced, leading to disruption of work schedules. The final major systems study was done for the Marine Corps in Twenty Nine Palms California. This was followed by a field feeding study for the US Army, studying the provision of food under field conditions rather than fixed facilities.

All of these studies required the identification of what factors contributed to customer satisfaction/dissatisfaction with the feeding system. This in turn required the development of questionnaires, interview protocols, and focus group protocols. The behavioral scientists had to master the techniques of attitude measurement and assessment. The largest effort involved in the systems studies was in consumer research. The Behavioral Sciences research group authored dozens of research reports on consumer research into military feeding systems from 1972 to 1990. The range of situations studied gave the researchers a broad perspective on military feeding, and on the methods necessary to conduct good field research (see Meiselman, 1984). This experience was invaluable in the later planning and successful execution of the long term eating studies of the early 1980 s.

Over many consumer research studies the researchers developed a hierarchy of consumer problems. When one factor was addressed, the next highest factor became the dominant complaint. Waiting in line was the biggest complaint, followed by food quality. However, when we switched the situation over to field feeding studies, the major complaint in the field became lack of a hot shower. The importance of non-food factors did not go unnoticed. These food studies directly led to the interest of the Natick group in contextual factors in food acceptance. Through exposure to customers in many different food service systems, the behavioral scientists became experts in consumer research in order to determine the factors that control satisfaction in institutional food service systems. The consumer research was carried out by the civilian scientists Lawrence Symington and Herbert Meiselman, working with the military officer scientists, Lawrence Branch, James Siebold, William Wilkinson, Earl Stein and Gene Chao. In the initial consumer work at Fort Lewis, Natick worked closely under contract with Fred Fiedler and Judith Fiedler at The University of Washington. Fred Fiedler was already working with the Army doing his 
well-known studies of leadership. Judith Fielder worked in the university survey research center, which conducted many of the interviews and surveys at Fort Lewis.

Another area of expertise developed around the training of food service personnel (cooks and others). This area was led by Lawrence Symington and Earl Stein, who conducted food service training studies for the Navy. The final area of expertise was the human factors of food service spaces and equipment. Lawrence Symington headed this area.

\section{Food habits and attitudes studies}

The work on human food habits focused most generally on food attitudes. The general study of what foods people like, and why they like them, is central to much of the product and system development work at Natick. Natick's food technologists, like food technologists in industry, were often insensitive to customers' preferences and assumed that any well-formulated item would be chosen and consumed. The systems studies for the military services included the delivery of fast foods to the young military population. New equipment and new food service layouts were needed to provide the fast food. And fast food helped to address the problem of long lines, which plagued military food service, especially shipboard feeding with large numbers of people in small spaces.

Food preferences of military personnel had been tracked in Chicago, and the first food preference study published by Natick was in fact contracted to David Peryam and Beverly Kroll, who were former employees of the Chicago lab. The Natick group, especially Meiselman (Meiselman \& Waterman, 1978), went on to regularly measure the food preferences of military personnel periodically from 1970s to 1990 s. The studies prior to 1970 utilized only hedonic scaling, while the studies after 1970 used both hedonic scaling and preferred frequency scaling. This shift resulted from the observation that menus are designed around two basic parameters, liking and time. Many food items are liked extremely, but are only desired with relatively low frequencies. This might apply to rich desserts. Other foods are liked moderately, but are eaten with much higher frequencies; this applies to many dietary staples such as bread, salad, etc.

The Natick researchers introduced some novel approaches to measuring food habits. Meiselman and his colleagues developed several ways of measuring preferred frequency. Moskowitz applied scaling procedures to issues of menu compatibility, menu combinations, and time preference relationships (that is, the preference for an item depending on when the item was last eaten). These considerations permitted the development of computergenerated menus. During this work, Moskowitz determined that about half of the acceptance of meals is determined by the acceptability of the main dish. This work was verified years later by researchers in England, and by Meiselman working with researchers in England. In the more recent work, Meiselman noted that in certain simpler meals such as pizza meals and sandwich meals, the main dish accounted for much more than half of the acceptability of the whole meal.

These food habits studies provided the opportunity to extend research on food preferences, by examining population demographics (age, race, gender, weight, geography) and by examining the different characteristics of the food. Wyant and Meiselman (1984) conducted studies of Air Force personnel and analyzed the data for gender and race. They demonstrated that women preferred vegetables, salads and fruits compared with men who preferred meat items. They also observed racial differences, with blacks liking fruit and fruit juices more than whites. Both race and gender could be predicted from food preferences.

One particularly challenging study was aimed at the food preferences of Air Force personnel assigned to extremely rigorous and isolated duty in Alaska. The Air Force had asked whether living in these conditions for 12 months required a different menu and diet. The research team was Herbert Meiselman, Earl Stein and R. Curtis Graeber. The study provided an opportunity to examine the relationship between food preferences and psychological state (neurosis). The study confirmed the previous observation that people who score more neurotic have more food dislikes. However, the results of the study did not lead to a recommendation of a different diet for these isolated military personnel.

In another adventuresome study, we analyzed the food preferences of US military personnel who would be required to eat the food of their host country in Europe. These socalled collocated servicemen would eat fish diets in Scandinavia and pork diets in Germany. We found that the preferences of US troops would indeed pose a challenge if they were required to eat local diets for lengthy time periods.

In the 1990s, two new dimensions were added to the measurement of habits and attitudes. The Natick group, primarily Cardello, Meiselman and Bell began to assess the role of measurable traits and attitudes on food acceptance. The new scales for Food Neophobia and Food Variety Seeking were added to the Natick repertoire for evaluating the responses to novel foods. Food Neophobia is of intrinsic interest in military rations, because the food often does not have its familiar shape, color and other sensory attributes. Food processing, packaging and storage can change attributes or make them harder to achieve in the first place. The Natick taste test panel, a panel of more than 300 volunteer employees, was tested on the Food Neophobia scale, so that subgroups could be drawn for tests. We noticed that the panel was in fact somewhat neophilic, which is not surprising in an educated group living in a Northeastern US urban area. Hely Tuorila, a Visiting Scientist from Finland, participated in some of this research on acceptance of novel foods utilizing the Food Neophobia Scale. More recently Bell and Marshall have developed a Food Involvement Scale, which is reported in one of the papers in this series. Bell, working with Meiselman, also 
undertook a large scale study of daily patterns of eating, using the cadets at the US Air Force Academy as the test sample.

Perhaps the most important area of food attitude research in the 1990s was the research of Cardello, working initially with Miles Sawyer from the University of Massachusetts. They began to explore the role of expectations on product acceptance. This work turned out to be very important in drawing other laboratories into the study of expectations. Cardello determined in a series of studies that food evaluations usually demonstrate the effect of assimilation, meaning that products are judged in the direction of their expectation. A product is judged better if people think it will be better than it actually is. Cardello related this to the poor stereotype of military products, where unfortunately military personnel assume military products will be disappointing. The expectation research at Natick was picked up by many other laboratories and scientists in the US and world-wide, and was facilitated again by Natick's Visiting Scientist Program and visitors such as Hely Tuorila. The role of expectations on food acceptance was a major Natick contribution of the 1990s.

Cardello, working with Schutz as a Visiting Scientist at Natick, has worked on a variety of food attitude studies including: the role of quality, meal appropriateness and preference in consumption and satisfaction; the development of an appropriateness to situation technique for tasted foods; development of a labeled affective magnitude scale that is more discriminating, especially among well liked foods than the hedonic scale and also allows for ratio statements; the influence of information on soldiers' concern and interest in eating foods processed by irradiation and other novel, nonthermal food processing/preservation techniques. Also they have recently been able to successfully apply many food acceptance and sensory evaluation techniques to the evaluation of military clothing fabrics and comfort.

\section{Long term eating studies}

Most research on eating takes place over relatively short time periods, often one meal or one day. In the early 1980s, the Natick Behavioral Scientists were presented with the challenge to study the acceptability of the military ration for long-term use. Military policy, influenced by the nutritional experts within The Surgeon General, accepted a diet based exclusively on packaged field rations (called Meals-ReadyTo-Eat, or MREs) for up to 10 days. As the medical organization of the Army, The Surgeon General determines the required nutritional content of the diet, including the minimum caloric level. Military planners wanted to know whether military rations could be fed for much longer, say 30 or more days. This would drastically change the way soldiers were supplied, because food was one of the major logistic requirements that determined how far and fast troops could move.

In 1983, Edward Hirsch and Herbert Meiselman began the planning and conduct of two prolonged feeding studies.
Hirsch conducted a controlled 45-day study at MIT with university students, who ate only military rations three meals per day. Hirsch and Meiselman conducted a 34-day field test using Army soldiers in an isolated location on the island of Hawaii (Hirsch et al., 1984).

These two long-term tests demanded entirely new designs for testing. Because of the length of the tests there were serious health concerns of weight loss and dehydration. We did not know whether soldiers would gain or lose weight, or remain stable; whether they would eat all or most of the $3600 \mathrm{kcal}$ ration, or very little. The study required a large team of researchers and technicians to stay on site for over one month, posing all sorts of logistic and cost problems for the study. This study would be very difficult to conduct in today's climate of increased human use oversight.

It is not an overstatement to say that the study revolutionized the way that Natick viewed and conducted research on eating (see Marriott, 1995). Despite doubts that the study could be conducted, the study was a great success and was followed by a series of other prolonged eating studies as other rations were developed and tested. The basic results of the first study surprised most people: acceptance ratings of rations remained stable, but soldiers ate progressively less over the duration of the test, and lost weight. The Natick group was faced with a dilemma, because their long-standing view had been that acceptance predicts consumption, and that there should be a high correlation between rated acceptance and consumption.

The results were similar but not identical in the MIT university study. Students also did not eat their entire ration, but ate much more than soldiers in the field. Students also lost weight, but a small amount, and students also rated their food as acceptable. These basic results have stood up over fifteen successive field tests: soldiers eat less in the field than in a cafeteria or laboratory, and food acceptance ratings are higher in the field than in the lab. Soldiers in the field eat about $2 / 3$ of what they are provided $(3600 \mathrm{kcal})$, and lose weight. The scientists at Natick have undertaken a review of their vast data base of the fifteen studies on field feeding to demonstrate two basic facts: providing more food does not always yield higher intake, and when higher amounts are provided, proportionately less food is consumed. These results are quite different than traditional laboratory studies, and demonstrate the value of conducting longer-term natural eating studies rather than short-term laboratory studies.

Aside from its military and theoretical importance, the first study prompted research into what factors control eating in the field. Prior research had focused on food factors and soldier factors. The third class of factors is contextual or situational factors that were receiving very little attention in the early 1980s. Natick was one of the first laboratories to identify and study them. Natick's changing view of what controlled eating and how to measure it began to shift and was reported in the 1987 Reading Conference on 
Food Acceptability hosted by David Thomson (Meiselman, Hirsch, \& Popper, 1988). Natick researchers were beginning to see food intake as a better measure of food acceptance than hedonic scaling when an entire system, rather than a product by itself in a laboratory was being investigated. And Natick researchers were beginning to understand the role of situational factors in these real eating situations, variables that might have little or no effect in the laboratory.

These developments gradually led to the development of a different scheme for testing products and systems. This new approach had seven different levels of testing, with the first two levels devoted to market research and individual items, the next two levels devoted to entire meals, the next two levels devoted to field testing, and the final level devoted to quality control. The seven-step testing scheme was designed by Meiselman, Hirsch and Cardello, and was published in the book on Measurement of Food Preferences by MacFie and Thomson (1994). Natick itself adopted the testing scheme and followed it for several years. However, over time, as financial resources became tighter, the scheme was gradually abandoned. All of the seven levels of testing were retained but they were not used in the sequence originally intended. Shortcuts were used to reduce testing costs. The seven-step scheme probably represents an idealized version of how to design and test consumer products for institutional markets. It provides a lesson or guideline on the right way to do the job, which must be balanced with financial and time constraints.

During the 1980s and 1990s Natick continued to conduct field tests of military rations, some short term and some long term. The tests were managed by Edward Hirsch, Dianne Engell, and Matthew Kramer. These 15 tests constitute one of the largest bodies of available data on how a population selects, consumes and evaluates their food. The studies contain data from thousands of people. The generality of the studies is restricted because the test population is almost entirely young healthy males eating outside, but the volume of data, and the relatively high control over the field situations makes the data a unique resource. The data have been featured in several reports by the Institute of Medicine, including the report 'Not Eating Enough' (Marriott, 1995). Other investigators are welcome to explore these data with us. For example, Cees de Graaf examined the relationship between acceptance and consumption within the entire data set during his tenure as a Visiting Scientist. A review of these studies appears in this series of papers (Kramer et al.).

\section{Contextual or situational factors}

Following the demonstration that eating in the field produced different results from eating in the laboratory, Natick scientists began to examine the variables that contribute to situational or contextual effects. To date a large number have been identified and studied.

Dianne Engell conducted our first study on the role of effort, demonstrating that more water was consumed when it was placed on the table in front of people than when it was placed across the room. In two studies in a student cafeteria, Meiselman demonstrated that increased effort sharply reduced selections of foods that had been moved to points farther away. Engell's study was conducted in a testing laboratory, while Meiselman's was conducted in a natural eating environment. Earlier, Meiselman had begun suggesting that contextual variables could be easily studied in natural eating environments (Meiselman, 1992).

John deCastro had already begun conducting his wellknown studies on social facilitation of eating, and social effects were integrated into Natick's contextual research program that followed the long-term feeding studies of the early 1980s. At Natick, Engell, Hirsch, Kramer and their colleagues began working with social variables. Engell, Kramer, Malafi, Salomon and Lesher (1996) showed the effects of effort and social modeling on water intake. Studies comparing garrison and field feeding also compared different levels of socialization in different field contexts.

Rick Bell and Herbert Meiselman examined the role of ethnic food identification studied in a natural eating environment. They obtained the collaboration of William Reeve, a chef at Bournemouth University, England, who prepared Italian and British versions of the same dishes. They used a restaurant that was decorated in either a British or an Italian theme, and observed that food choices changed with the switch to an Italian theme, for example, leading to the selection of more pasta. Meiselman examined pricing effects in a student cafeteria that previously had sold itempriced foods. Student selections changed when a special meal of the day at a set price was offered. This set meal increased the selection of vegetables, showing that pricing can affect meal quality.

Another way of looking at contextual factors is to examine different contexts directly. Beginning in 1994, Meiselman began working with John Edwards and William Reeve at Bournemouth University in England and then with Jennifer Crouch at East Carolina State University in North Carolina. The purpose of these studies (Meiselman, Johnson, Reeve, \& Crouch, 2000) was the direct comparison of the same food served in different contexts. The results showed that restaurant (non-institutional) food was rated higher than the same food served in institutional settings. Further it appears that consumers in institutions catering to younger people rate food less positively than do those in institutions serving middle-aged and older people. In a questionnaire study of young people's expectations of food quality, Cardello had found a similar expectation that institutional food would be less acceptable. Edwards and Meiselman have greatly extended the range of locations studied (Edwards, Meiselman, Edwards, \& Lesher, 2003).

\section{Diet and performance}

During the early research years at Natick and during the Systems Analysis studies, the relationship between diet and performance was not a focus of study. In several review papers, Harry Jacobs hypothesized about the relationship of 
diet to performance, but he emphasized the contemporary dietary emphasis on over-nutrition that was popular in the 1970s. He saw the military feeding situation as another example of how overeating could contribute to performance decrements. The long-term feeding studies of the 1980s and 1990s raised the question of whether under-nutrition was a better model for soldiers in the field.

During the $1980 \mathrm{~s}$, a program began in diet and performance, titled Performance Enhancing Ration Components. This collaborative program involved ration developers (food technology), nutritionists, and behavioral scientists who conducted many of the ration tests. This program was designed to enhance military performance through selection of proper ration components in the proper amounts. Interested readers are referred to the chapters by Lieberman and by Young and Montain in this series of papers.

\section{Research for other government agencies}

Other government agencies asked the Natick behavioral researchers to undertake contract research for three reasons. First, few if any research groups had the broad expertise of the Natick group. Second, the Natick group had extensive field experience while at the same time the researchers were all trained laboratory scientists. Third, the Natick group had adequate resources (mainly personnel) to support largescale studies. And probably a fourth reason is that the Natick group was interested in broader issues that came with the different sponsors.

The first non-Army research sponsor was the United States Department of Agriculture (USDA) that sponsored research on the acceptability of a whey-soy mix as a supplementary food for pre-school children in developing countries. This project (Rodier et al., 1973) was headed by Jacobs and Graeber at Natick working with outside contractors, and looked like a straight food acceptance study. But it involved the issues of field-work with mothers and children, and measurement with non-literate populations.

Related work came from the US Department of Agriculture, which managed the US school lunch program. The work involved a focus on food waste, more than on what was consumed or what was liked or disliked (Comstock, Symington, Chmielinski, \& Mcguire, 1979). This study, headed by Elizabeth Comstock and Lawrence Symington, added to the Natick expertise by familiarizing the staff with waste measurement, and then applying it to the school cafeteria.

The next opportunity was also more related to nutrition than to product acceptance, and was sponsored by the Food and Drug Administration, which asked Natick to undertake a validation study of different methods of individual food intake measurement. The comparison of dietary recalls, records, and food frequency lists is one of the thorniest issues in the field of food habits measurement. Herbert Meiselman ran this study for Natick, working with Howard
Schutz and Nora Krantzler of UC Davis and Nathan Macoby of Stanford University (Krantzler et al., 1982; Mullen, Krantzler, Grivetti, Schutz, \& Meiselman, 1984).

Another external opportunity involved the evaluation of the sensory and hedonic properties of underutilized fish species for the US Department of Commerce/National Marine Fisheries Service. The problem was to develop a framework by means of which underutilized fish species could be grouped according to their edibility characteristics. The approach involved developing a standardized methodology for assessing edibility criteria of fish species (Cardello, Sawyer, Prell, Maller, \& Kapsalis, 1983). Sensory and instrumental profiles of underutilized fish species were compared to profiles of well-known species. The research produced groupings of similar tasting species that could be used in retail fish markets to assist customers in making decisions about purchases based on the similarity in the flavor (texture, etc.) of the underutilized fish relative to the flavor of fish with which the consumer was more familiar.

In the 1980s, there was internal pressure to focus the work more on Army needs, and the ability to attract and conduct work for other agencies diminished. However, the experiences were valuable for broadening the perspective of the Natick researchers, and for exposing them to other feeding systems and other product problems.

\section{Services program}

The tradition of the Behavioral Sciences, even while in Chicago, was a combination of research and service work. Thus, the Chicago group started and maintained the Food Acceptance Laboratory. This Laboratory moved to Natick before Jacobs arrived, and was in operation before his arrival. However, from the beginning, the Acceptance Laboratory provided a key role in the development of the Natick research program. The laboratory had a large central kitchen, and test booths for 11 panelists. The laboratory had its own dedicated staff of assistants to prepare samples, carry out the tests, and analyze the data. The Acceptance Laboratory presented a unique opportunity to conduct basic research, and many of the scientists at Natick made use of this opportunity.

The Acceptance Laboratory is an applied facility that conducts tests of Natick products during development and also tests foods that are being considered for procurement by the Defense Department. The most frequent tests conducted in the Acceptance Laboratory are pre-procurement tests and shelf-life tests. The preprocurement tests compare the acceptance of samples provided by contracts against standards, and the results have to meet certain criteria. The shelf-life tests track the ratings of samples that are held for long periods of time, and tested periodically. Perhaps 500 portions of an item are stored at various temperatures for three years, and 100 portions are removed each year and tested. In this 
way, the food technologists can determine the shelf life of the item. Long shelf life is a unique requirement of the military that puts greater demands on food formulation and packaging. Natick also participated in the testing of items from the Food Irradiation Program, which had been begun at Chicago, and which was eventually transferred to the US Department of Agriculture.

Another service provided during the Chicago days that was carried to Natick was the design and execution of food preference surveys. These surveys are designed to provide military menu planners with information on what soldiers want to eat. The data are also used by food-product developers to guide which items to add and which items to drop from military rations. There were three main changes in these surveys at Natick. First, in 1974, the overall food research program at Natick changed from a strictly Army program to a Department of Defense Food Program, serving the needs of all four services (Army, Navy, Air Force, Marines). All of these four services requested assistance with the assessment of food preferences. This greatly broadened the scope of the food preference work. Furthermore, Herbert Meiselman was officially appointed as the technical advisor to the Armed Forces Menu Service Committee, for the first time giving the menu planners direct access to the data, and giving the scientists direct access to the needs of the menu planners. Also, during the 1970s, the military began to see a large change in the demographic composition of the services, thus requiring better design of food preference surveys and better sampling of respondents. And finally, American food habits were themselves changing with the introduction of fast foods and ethnic foods.

The third major service area was one which was unique to Natick, and had not been practiced in Chicago. As noted above, in 1970, Natick began an Operations Research and Systems Analysis Office that undertook a long series of systems studies of military feeding. These studies addressed field conditions, garrison or cafeteria conditions, and specialized conditions such as Navy ship-board conditions. The systems analysts, headed by Robert Byrne, placed the customer and the cook (the two human parts of the system) in high priority places in the new emerging systems. This was remarkable, because at this time 'customer orientation' was certainly not widespread, and within the military the customer was seen as someone who did what he was told. The systems analysts understood that one cannot run a successful food service system, even within the military, without considering the customer. When the systems analysts began their work, they turned to their local psychologists in Behavioral Sciences to assist them in the design, planning, and testing of new food service systems (see Branch \& Meiselman, 1972; Kiess et al., 1972). A number of psychologists joined in the new work, which is reported under the section on The Research Program.
The systems studies of food service lasted about 20 years from 1970 to 1990 .

The work conducted for the systems analysts resulted in the development of an expertise that is widely sought after and utilized at Natick, the area of questionnaire design and analysis. The psychologists at Natick are called upon by Natick managers, other Army and government managers, and those in private industry to design or evaluate questionnaires, and sometimes, to administer and analyze them. For many years (in the 1980s) the Behavioral Sciences administered the personnel surveys within Natick that were use by Natick management to make important personnel and programmatic decisions.

\section{Conclusion}

The US Army, first at the QMFCI in Chicago, and later at the Natick Laboratories in Massachusetts have contributed greatly to the development and growth of the study and evaluation of food acceptance. Over the second half of the 20th century, a large number of scientists and technologists working in Chicago or Natick have developed techniques for the measurement of food acceptance and its controlling variables. They have developed techniques for the evaluation of acceptability in both laboratory and field settings. They have published hundreds, perhaps thousands, of papers on their studies, because their work is not proprietary as is the case in industry.

The Chicago and Natick scientists tended to work in interdisciplinary teams, which included academic collaborators working under contract and visiting scientists from other institutions and sometimes from other countries. The team-work had an atmosphere that reflected a great deal of comraderie and a sense of excitement and contribution to both the theoretical and practical problems in food acceptance. The people who worked and trained at these two laboratories can be found in academia and industry all over the United States. The Visiting Scientists can be found all over the United States, and in many leading research institutes around the world. While other centers of excellence in food acceptance research have come and gone, the role of the US Army in food acceptance research has continued uninterrupted since the 1940s. Centers of excellence have periodically developed in Europe, while expertise in the US has mainly centered within academic departments where the investigators work independently.

In both Chicago and Natick there was a nurturing of contacts and ties with government entities, such as the National Academy of Sciences, and with academia. In both Chicago and Natick there were ties to industry and to the market research community.

Chicago and Natick worked on a number of continuing themes: basic human sensory processes, basic and applied sensory evaluation methods, laboratory testing and field testing, human food habits and their controlling variables, 
food preferences and their relation to other food behaviors, food attitudes, food habits such as monotony and satiety, product development, and the relationship of diet to performance. While it is very risky to attempt to select the major technological and methodological achievements from Chicago and Natick, we have decided to accept the risk and put forth our opinions, which have been worked out with our colleagues at Natick. The List of Technological/Methodological Achievements (Table 4) includes 16 topics beginning with the hedonic scale, continuing through psychophysical topics, food habits topics, and various measurement topics. While other people might add or

Table 4

Technological/methodological achievements in Army acceptance research

1. Development and validation of nine-point hedonic scale

2. Development of one of the first sensory evaluation laboratories in the 1940s and the first laboratory devoted to 'Food Acceptance'

3.

Psychophysical studies of taste stimuli, taste adaptation, and taste mixtures using direct scaling, and taste mechanisms using taste modifiers, single papillae, etc.

4. Psychophysical studies of smell, and smell mixtures using direct scaling

5. Psychophysical studies of texture and relationship to instrumental measures

6. Direct scaling of hedonic aspects of food stimuli and their relationship to sensory attributes

$7 . \quad$ Scaling of food preferences, food compatibility, boredom, menu planning

8. Long term study of food preferences among military personnel

9. Development of methodology for evaluating foods (rations) in the field including acceptance and intake; observation of low consumption along with stable acceptance

10. Introduced consumer research, including food acceptance, as part of studies of institutional (military) food service systems

11. Sensory and consumer studies on acceptance of novel/irradiated foods, including the role of food habits and attitudes such as monotony, variety and neophobia

12. Application of expectation theory to food acceptance

13. Studies of environmental/contextual variables and their impact on choice, intake and acceptance

14. Application of food sensory evaluation to other products (clothing comfort)

15. Exploration of the relationship between laboratory and field data, between laboratory acceptance and field acceptance, and in general, the effects of eating location on choice and acceptance

16. Exploration of the relationship of acceptance to intake subtract from this list, we hope that it conveys the broad and continuing developments coming from Chicago and Natick.

Chicago and Natick were unlike any other laboratories conducting research on food acceptability. Their unique combination of staff, resources, and mission permitted them to survive and prosper, and to continuously contribute to the field of food acceptance for over one half century. At the beginning of the 21 st century, the future is still promising.

\section{Acknowledgements}

This Special Section of Appetite on US Army Research was guest edited by H.L. Meiselman, F.H. Kramer, J. Dwyer and P. Pliner. We wish to thank our colleagues Linda Bartoshuk, Armand Cardello, Edward Hirsch, Harry Jacobs, Joseph Kamen and Virgil Wodicka for providing material and for reading earlier versions of this paper. We accept responsibility for omissions and commissions.

\section{References}

Bell, B. L., Oshinsky, N. S., \& Wolfson, J (1965). Food acceptance and preference research: An annotated bibliography. US Army Natick Laboratories Technical Report EPT-5, 58 pp

Branch, L. G. \& Meiselman, H. L (1972). Consumer reaction to the Fort Lewis CAFé system. US Army Natick Laboratories Technical Report 72-64-PR

Cardello, A. V., Sawyer, F. M., Prell, P., Maller, O., \& Kapsalis, J. (1983). Sensory methodology for the classification of fish according to 'edibility characteristics'. Lebensmitel Wissenschaft und-Technologie, 16, 190-194.

Committee on Food Research (1945). Food Acceptance Research Conference. December.

Comstock, E. M., Symington, L. E., Chmielinski, H. E., \& Mcguire, J. S (1979). Plate waste in school feeding programs: Individual and aggregate measures. US Army Natick Research and Development Laboratories Technical Report TR-81/011, $101 \mathrm{pp}$.

Dove, W. F. (1943). Appetite levels of food consumption. Human Biology, 15(3), 199-220.

Dove, W. F. (1947). Food acceptability: Its determination and evaluation. Food Technology, 1, 39-50.

Edwards, J. S. A., Meiselman, H. L., Edwards, A., \& Lesher, L. (2003). The influence of eating location on the acceptability of identically prepared foods. Food Quality and Preference, in press.

Eindhoven, J., \& Peryam, D. R. (1960). Measurement of preferences for food combinations. Food Technology, 13(7), 379-382.

Engell, D., Kramer, M., Malafi, T., Salomon, M. \& LESHE, I (1996). Effects of effort and social modeling on drinking in humans. Appetite, 26(2), 129-138.

Halpern, B. P., \& Meiselman, H. L. (1980). Taste psychophysics based on a simulation of human drinking. Chemical Senses and Flavor, 5, 279-294.

Hirsch, E., Meiselman, H. L., Popper, R. D., Smits, G., Jezior, B., (Natick), Lichton, I., Wenkhma, N., Burt, J., Fox, M., McNutt, S., Thiele, M. N., \& Dirige (U. Hawaii) (1984). The effects of prolonged feeding meal, ready-to-eat (MRE) operational rations. US Army Natick Research and Development Center Technical Report TR-85/035, 357 pp.

Jones, L. V., Peryam, D. R., \& Thurstone, L. L. (1955). Development of a scale for measuring soldiers' food preferences. Food Research, 20(5), $512-520$. 
Kiess, H. O., Swanson, J. B., \& Johnson, R. F. Q (1972). Fort Lewis dining facilities consumer survey. US Army Natick Laboratories Technical report, TR72-44 PR, 23 pp plus appendices.

Krantzler, N. J., Mullen, B. J., Schutz, H. G., Grivetti, L. E., Holden, C. A., \& Meiselman, H. L. (1982). Validity of telephoned diet recalls and records for assessment of individual food intake. Journal of Clinical Nutrition, 36, 1234-1242.

Macfie, H. J. H., \& Thomson, D. M. H. (1994). Measurement of food preferences Gasgow: Blackie Academic and Professional.

Marriott, B. (Ed.), (1995). Not eating enough: Overcoming underconsumption of military operational rations (p. 483) Washington: National Academy Press.

Meiselman, H. L. (1981). Variables affecting the psychophysical function for taste. Olfaction and taste VII, London: IRL Press, pp. 359-362.

Meiselman, H. L. (1984). Consumer studies. In J. R. Piggott (Ed.), Sensory analysis of foods (pp. 243-304). Barking, England: Applied Science Publishers.

Meiselman, H. L. (1992). Methodology and theory in human eating research. Appetite, 19, 49-55.

Meiselman, H. L., Hirsch, E. S., \& Popper, R. D. (1988). Sensory, hedonic and situational factors in food acceptance and consumption. In D. M. H Thomson (Ed.), Food acceptability (pp. 77-88) London: Elsevier Applied Science.

Meiselman, H. L., Johnson, J. L., Reeve, W., \& Crouch, J. E. (2000). Demonstrations of the influence of the eating environment on food acceptance. Appetite, 35, 231-237.

Meiselman, H. L., \& Waterman, D. (1978). Food preferences of enlisted personnel in the Armed Forces. Journal of the American Dietetic Association, 73, 621-629.

Mullen, B. J., Krantzler, N. J., Grivetti, L. E., Schutz, H. G., \& Meiselman, H. L. (1984). Validity of a food frequency questionnaire for determination of individual food intake. American Journal of Clinical Nutrition, 39, 136-143.

Peryam, D. R. (1958). Sensory difference tests. Food Technology, 12(5), $231-236$.

Peryam, D. R., \& Girardot, N. F. (1952). Advanced taste-test method. Food Engineering, July, 58-61. see also page 194.

Peryam,D. R., \& Haynes, J. G. (1957). Prediction of soldiers' food preferences by laboratory methods. Journal of Applied Psychology, 41(1), 2-6.

Peryam, D. R., \& Pilgrim, F. J. (1957). Hedonic scale method of measuring food preferences. Food Technology, 11(9), 9-14.

Peryam, D. R., Pilgrim, F. J., \& Peterson, M. S (1954). Food acceptance testing methodology. A symposium sponsored by the QMFCI, National Academy of Sciences-National Research Council.

Peryam, D. R., Polemis, B. W., Kamen, J. R., Eindhoven, J., \& Pilgrim, F. N (1960). Food preferences of men in the Armed Forces. Department of the Army Quartermaster Food and Container Institute, $160 \mathrm{pp}$.

Pilgrim, F. J. (1957). The components of food acceptance and their measurement. American Journal of Clinical Nutrition, 5(2), 171-175.

Pilgrim, F. J., \& Kamen, J. M. (1963). Predictors of human food consumption. Science, 132(3554), 501-502.

Rodier, W. I., III, Wetsel, W. C (USDA), Jacobs, H. L., Graeber, R. C., Moskowitz, H. R., Reed, T. J. E., \& Waterman, D (Natick) (1973). The acceptability of whey-soy mix as a supplementary food for pre-school children in developing countries. US Army Natick Laboratories Technical Report 74-20-PR, 15 pp.

Schutz, H. G., \& Pilgrim, F. J. (1957a). Differential sensitivity in gustation. Journal of Experimental Psychology, 44(1), 41-48.

Schutz, H. G., \& Pilgrim, F. J. (1957b). Sweetness of various compounds and its measurement. Food Research, 22(2), 206-213.

Schutz, H. G., \& Pilgrim, F. J. (1958). A field study of monotony. Psychological Reports, 4, 559-565.

Siegal, P. S., \& Pilgrim, F. J. (1958). The effect of monotony on the acceptance of food. American Journal of Psychology, 71, 756-759.

Wyant, K., \& Meiselman, H. L. (1984). Sex and race differences in food preferences. Journal of the American Dietetic Association, 84, $169-175$.

\section{Further Reading}

Bartoshuk, L. M. (1968). Water taste in man. Perception and Psychophysics, 3, 69-72.

Bartoshuk, L. M., Dateo, G. P., Vandenbelt, D. J., Buttrick, R. L., \& Long, L., Jr. (1969). Effects of Gymnema sylvestre and Synsepalum dulcificum on taste in man. In C. Pfaffman (Ed.), Olfaction and taste (pp. 436-444). New York: Rockefeller University Press.

Cardello, A. V. (1979). Psychophysical exponents for single papillae: A comparison with whole mouth exponents. Perception and Psychophysics, 25, 510-516.

Cardello, A. V., Hunt, D., \& Mann, B. (1979). Relative sweetness of fructose and sucrose in model solutions, lemon beverages, and white cake. Journal of Food Science, 44, 748-751.

Cardello, A. V., Maller, O., Bloom-Masor, H., duBose, C., \& Edelman, B. (1985). The role of consumer expectancies in the acceptance of novel foods. Journal of Food Science, 50, 1707-1718.

Cardello, A. V., Maller, O., Kapsalis, J. G., Segars, R. A., Sawyer, F. M., Murphy, C., \& Moskowitz, H. R. (1982). The perception of texture by trained and consumer panelists. Journal of Food Science, 47, 1186-1197.

Cardello, A. V., \& Murphy, C. (1977). Magnitude estimates of gustatory quality changes as a function of solution concentration of simple salts. Chemical Senses and Flavor, 2, 327-339.

Cardello, A. V., \& Sawyer, F. M. (1992). Effects of disconfirmed consumer expectations on food acceptability. Journal of Sensory Studies, 7(4), $253-278$.

Edelman-Lewis, B., Hirsch, E., Engell, D., \& Bronstein, P. (1986). The effects of portion size and feeding environment on food intake in normal weight and overweight people. Appetite, 7, 71-83.

Jacobs, H. L., \& Sharma, K. N. (1969). Taste vs. calories: Sensory and metabolic signals in the control of food intake. P. J.Morgane, New York: Annals of the NY Academy of Science, 157, 1084-1125.

Kamen, J. M., Peryam, D. B., Peryam, D. R., \& Kroll, B. J (1967). Studies on acceptance testing methodology: Preliminary studies on characteristics of taste panel, sample size, and contrast and convergence effects. US Army Natick Laboratories Technical Report 68-10-PR (under contract).

Kamen, J. M., Pilgrim, B. J., Kroll, B. J., \& Gutman, N. J. (1961). Interactions of suprathreshold taste stimuli. Journal of Experimental Psychology, 62, 348-356.

Maller, O., Cardello, A. V., Sweeney, J., \& Shapiro, D. (1982). Psychophysical and cognitive correlates of discretionary usage of salt and sugars by humans. In J. Steiner, \& J. Ganchrow (Eds.), Determination of behavior by chemical stimuli (pp. 205-218). London: Information Retrieval Limited Press.

Meiselman, H. L. (1994). A measurement scheme for developing institutional products. In D. Thomson, \& H. J. H. MacFie (Eds.), Measurement of food preferences (pp. 1-24). Glasgow: Blackie Academic.

Meiselman, H. L., Hedderley, D., Staddon, S. L., Pierson, B. J., \& Symonds, C. R. (1994). Effect of effort of meal selection and meal acceptability in a student cafeteria. Appetite, 23, 43-55.

Meiselman, H. L., \& Macfie, H. J. H. (Eds.), (1996). Food choice acceptance and consumption. Glasgow: Blackie Academic and Professional, contains Natick chapters.

Meiselman, H. L., \& Rivlin, R. S. (Eds.), (1985). Clinical measurement of taste and smell. New York: MacMillan, contains Natick chapters.

Moskowitz, H. R. (1970). Ratio scales of sugar sweetness. Perception and Psychophysics, 7, 316-320.

Moskowitz, H. R. (1972a). Economic applications of sweetness scales. Journal of Food Science, 37, 624-626.

Moskowitz, H. R. (1972b). Subjective ideals and sensory optimization in evaluating perceptual dimensions of food. Journal of Applied Psychology, 56(1), 60-66. 
Moskowitz, H. R. (1977). The nature of acceptability functions in texture. Journal of Texture Studies, 7, 235-242.

Moskowitz, H. R., \& Kapsalis, J. G. (1976). Psychophysical relations in texture. In J. DeMan, V. Raspar, D. W. Stanley, \& P. W. Voisey (Eds.), Rheology and texture in food quality (pp. 554-581). Westport, CT: AVI Press.

Moskowitz, H. R., Kapsalis, J. G., Cardello, A. V., Fishkin, D., \& Maller, O. (1979). Determining relationships among objective, expert, and consumer measures of texture. Food Technology, 33, $84-88$.

Moskowitz, H. R., \& Sidel, J. L. (1971). Magnitude and hedonic scales of food acceptability. Journal of Food Science, 36, 677-680.

Pangborn, R. M., Guinard, J.-X., \& Meiselman, H. L. (1989). Evaluation of bitterness of caffeine in hot chocolate drink by category, graphic, and ratio scaling. Journal of Sensory Studies, 4, 31-53.

Polemis, B. W. \& Jones, W. H (1950). Food preference study conducted at Fort riley, Kansas, August 1949. Quartermaster Food and Container
Institute for the Armed Forces Interim Report No. 1 on project 7-84-1501

Popper, R., Smits, G., Meiselman, H. L., \& Hirsch, E. (1989). Eating in combat: A survey of US Marines. Military Medicine, 154, 619-623.

Quartermaster Food and Container Institute (1945). The problem of food acceptability. Committee on Food Research, National Academy of Sciences-National Research Council.

Sandick, B., Engell, D. B., \& Maller, O. (1984). Perception of drinking water temperature and effects for human after exercise. Physiology and Behavior, 32, 851-855.

Teghtsoonian, M., Becker, E., \& Edelman, B. (1981). A psychophysical analysis of perceived satiety: Its relation to consumatory behavior and degree of overweight. Appetite, 2, 217-229.

Weiffenbach, J. M (Ed.) (1977). Taste and development: The genesis of sweet preference. DHEW Publication No (NIH) 77-1068. Washington: US Government Printing Office 017-047-00009-4 (contains many Natick chapters). 